\title{
Back to Basics - European Copyright Law after the DSM Directive
}

\author{
Katharina de la Durantaye
}

Published online: 13 October 2021

(C) The Author(s) 2021

European copyright lawyers are exhausted. Over the past few years, the European Union has enacted a host of new copyright directives, ${ }^{1}$ the legislative activity famously culminating in the Directive on copyright and related rights in the Digital Single Market (DSM Directive). ${ }^{2}$ Now that this directive is in force and has been transposed by most EU Member States, the European Commission has shifted its focus away from copyright law. The next few years will probably bring about paradigm-shifting regulation of the platform economy, ${ }^{3}$ but it is unlikely that we will witness another major legislative measure in copyright law before the year 2030.

It might be tempting for us academics to sit back and observe how the EJC does its magic in interpreting the DSM Directive ${ }^{4}$ (as well as the other new directives), and in streamlining the varying approaches which the Member States have shown during the implementation process. While that temptation is understandable, I think it is wrong. We should not arrange ourselves with the status quo and confine our

\footnotetext{
${ }^{1}$ Directive on certain permitted uses of orphan works (2012/28/EU); Directive on collective management of copyright and related rights and multi-territorial licensing of rights in musical works for online use in the internal market (2014/26/EU); Directive on certain permitted uses of certain works and other subject matter protected by copyright and related rights for the benefit of persons who are blind, visually impaired or otherwise print-disabled (2017/1564/EU); Directive on copyright and related rights applicable to certain online transmissions of broadcasting organizations and retransmissions of television and radio programs (2019/789/EU).

2 Directive (EU) 2019/790.

3 Cf. the Commission's proposals for a Digital Services Act (COM/2020/825 final) and a Digital Markets Act (COM/2020/842 final).

4 Poland already challenged the constitutionality of the Directive's notorious Art. 17, $c f$. ECJ, Case C-401/19 - Republic of Poland v. European Parliament and Council of the European Union.
}

K. de la Durantaye $(\bowtie)$

LL.M. (Yale); Professor of Civil Law, Business, Competition and Intellectual Property Law, Freie Universität Berlin, Berlin, Germany

e-mail: katharina.durantaye@fu-berlin.de 
energies to critically analyzing its interpretation. Now, more than ever, we should concern ourselves with the fundamentals of copyright law, and we should force the legislature to do the same. ${ }^{5}$ Copyright law determines how we communicate in a digital society, and so plays a key role in a pluralistic democracy. Yet the main narratives upon which its rules are built remain basically unchallenged. While drafting the DSM Directive, both European and national legislatures bought into and retransmitted the old stories which the lobbyists fed to them. In Brussels as well as in Berlin, Paris and elsewhere, traditional and economically very powerful corporations in the creative industries purported to represent the interests of penniless, creative authors, while equally powerful online service providers purported to represent the interests of penniless, creative internet users. Obviously, neither of these claims hold.

The first lesson to be learned from the DSM Directive is that we should begin to disentangle these narratives and identify all of copyright law's players (which would include society at large). We should then examine each of those players' interests, and the constraints under which they operate. By doing so, we would not only help make the copyright discourse more honest, we would also lay the groundwork for devising rules that reflect the true and often complex economic and societal interests at stake. We should take account of the fact that copyright law covers a host of subsystems with differing societal norms and differing modes of distribution. Exploring them would require us to do empirical work, which is something that most lawyers are not very well equipped to do. We might thus want to broaden our perspective and collaborate with colleagues from other disciplines.

There are other respects in which the DSM Directive is interesting because of what the legislature did not consider or, at least, did not openly discuss. The Directive strengthens certain current trends in copyright law without making that explicit, and without examining their implications in greater detail. ${ }^{6}$ One of these trends is that copyright law contains ever more procedural rules in addition to or instead of substantive rules. The better part of Art. 17 DSM Directive lays down procedural requirements which online content-sharing service providers must fulfil. Similarly, most of the articles dedicated to copyright contract law (Arts. 19-21 DSM Directive) and part of the articles on extended collective licenses (Arts. 8-12 DSM Directive) are of a procedural nature.

More profoundly, over the past decade, the European legislature (along with European and other courts $)^{7}$ carved out areas where copyright's traditional opt-in model was replaced by an opt-out one: ${ }^{8}$ A rights holder can assert his or her property rights only if he or she complies with certain procedural requirements.

\footnotetext{
${ }^{5}$ For a memorandum on the future of the creative ecosystem in Europe which deals, among others, with the aspects mentioned in this text, $c f$. de la Durantaye and Grünberger, GRUR Int. 2021, p. 380.

${ }^{6}$ For a more profound analysis of the trends discussed herein, $c f$. de la Durantaye and F. Hofmann, ZUM 2021, p. 873.

${ }^{7}$ One only needs to look at the ECJ's recent decision on framing, ECJ, Case C-392/19 - VG Bild-Kunst v. Stiftung Preußischer Kulturbesitz. For a similar trend in patent law, $c f$. ECJ, Case C-170/13 - Huawei Technologies Co. Ltd. v. ZTE Corp., ZTE Deutschland GmbH.

${ }^{8}$ Cf. Wielsch, GRUR 2011, pp. 665, 670; Hofmann, ZUM 2019, pp. 617, 620; Grünberger, ZUM 2020, pp. 50,51 .
} 
Even if the Orphan Works Directive is not of great practical use, it does establish that orphan works might be used without the right holder's permission; if they want to prevent the use, they must take active steps. Thanks to the DSM Directive, collecting societies may now grant extended collective licenses for out-ofcommerce works as well as in other circumstances. ${ }^{9}$ Rights holders who wish to exercise their property rights must actively claim them (Art. 8 para. 4; Art. 12 para. 3 lit. (c) DSM Directive). So far, though, this has not led to a more fundamental discussion as to whether, and in which areas, we might want to make use of the opt-out model to balance the various competing interests at stake. Again, it is up to us academics to lay the groundwork for a broader and more informed public discourse.

The same is true for the closely connected question of whether we want a greater level of formalization in copyright law. In theory, authors do not have to fulfil any formal requirements in order to obtain copyright protection for their works. In practice, though, rights holders can only fully exploit their works in digital ecosystems if these works are contained in the registers of collecting societies and/ or online service providers (think YouTube's Content ID). Article 17 DSM Directive creates additional incentives for rights holders to contribute to these private registers. Where the works at stake have little economic value but are possibly culturally very valuable, the legislature went even further and made registration mandatory. We now have pan-European registers for orphan as well as for out-of-commerce works (Art. 3 para. 6 Orphan Works Directive; Art. 10 DSM Directive). Unlike classic IP registers, these registers are not filled by rights holders but by prospective users (or collecting societies). The creation of these digital registers, be they private or public, has been relatively uncontroversial, perhaps because it has not been accompanied by a principled discussion about the ban on formalities in copyright law. We should not shy away from such a discussion, though. Since all works which are economically and/or culturally valuable are contained in some form of digital register, it might be time to examine whether we should stick to the ban. Would it make sense to require rights holders to register their works if they want to keep protection after a certain time period?

Many more basic questions can be extracted from the DSM Directive, none of which were really discussed during the legislative process, and each of which would make for valuable research. To what extent should we collectivize copyright law? What role should market solutions play, and where does the market fail? What is the right relationship between law and technology? And, most importantly, what is the role of copyright law today? Which goals should it serve, which problems should it solve - and which ones are better left to competition law, data protection, labour law or contract law? There is much work to be done, and we should begin to do it.

Funding Open Access funding enabled and organized by Projekt DEAL.

\footnotetext{
9 While Arts. 8-11 DSM Directive which are dedicated to extended collective licenses for out-ofcommerce works must be transposed into national law, Art. 12 DSM Directive allows but does not require Member States to provide for extended collective licenses in other circumstances.
} 
Open Access This article is licensed under a Creative Commons Attribution 4.0 International License, which permits use, sharing, adaptation, distribution and reproduction in any medium or format, as long as you give appropriate credit to the original author(s) and the source, provide a link to the Creative Commons licence, and indicate if changes were made. The images or other third party material in this article are included in the article's Creative Commons licence, unless indicated otherwise in a credit line to the material. If material is not included in the article's Creative Commons licence and your intended use is not permitted by statutory regulation or exceeds the permitted use, you will need to obtain permission directly from the copyright holder. To view a copy of this licence, visit http:// creativecommons.org/licenses/by/4.0/.

Publisher's Note Springer Nature remains neutral with regard to jurisdictional claims in published maps and institutional affiliations. 